\title{
Evaluation of Competitiveness of Ceylon Tea in the World Market
}

\author{
K.H.S Kumara Kithsiri ${ }^{1 *}$, V.S. Jayamanna², L. M Abewickrama²
}

${ }^{1}$ Tea Commissioner's Division, Sri Lanka Tea Board, Head Office, 574, Galle Road, Colombo 03, Sri Lanka.

${ }^{2}$ Department of Food Science, Faculty of Agriculture, University of Ruhuna, Mapalana, Kamburipitiya, Sri Lanka.

${ }^{2}$ Department f Agric. Economics and Extension, Faculty of Agriculture, University of Ruhuna, Mapalana, Kamburipitiya, Sri Lanka.

\section{Correspondence:}

1 skumarakithsiri@yahoo.com ORCID: 0000-0003-3563-417X

\begin{abstract}
Competitiveness and being competitive is vitally needed to enhance the performance and to tackle challenges in the highly competitive world tea market. The prestige brand Ceylon Tea established in the past has been enjoyed by Sri Lanka having no analysis done to determine the competitiveness of Ceylon Tea in its major destinations. This study was carried out by using the CMS model to determine the competitiveness and to test the possibility of using the model for such purposes. The total change of exported quantity to a particular country could be differentiated into three corporates such as market growth effect, composition effect and the residual effect or competitive effect by using the Constant Market Share (CMS) model. Fifteen destinations of Ceylon Tea markets were selected for the study based on the total quantity of Ceylon Tea exported and the potential of the country to import Ceylon Tea. Tea import data of last fifteen years from 2003 to 2015 were used for the study. The results revealed that Ceylon Tea is found to be competitive in Russia, Kuwait, Japan, Turkey, Germany, Australia, USA, and India, and Azerbaijan, Iran, UK and Libya are found to be having potential for being competitive for Ceylon Tea. However, Sri Lanka could have maintained its share of export and increased the market share in many of these destinations by enhancing the market growth as well as composition effect. Therefore, this model could be used to determine the competitiveness of Ceylon Tea in its destination. Further, tea promotion policy decisions including brand promotion through effective marketing communication could be achieved.
\end{abstract}

Keywords: Ceylon Tea, CMS model, Competitive advantage 


\section{Introduction}

Tea is manufactured from the tea plant (Camellia sinensis) and considered as the most consumed beverage in the world. Due to the specific condition of the soil and the climate, the tea plantation has been limited to five special regions in the world. Most tea manufacturing countries are located in the Asian continent. China, India, Sri Lanka are the top producers in the continent. Kenya, Tanzania, Malawi, and Uganda are the African tea-growing countries located mostly in the tropical regions. In addition to Asian and African regions South American countries (Argentina, Brazil, and others), countries near the Fareast (Turkey and Iran) and Georgia and Russia in the CIS region manufacture significant amounts of tea (Majumder et al. 2008).

Being the top producers and exporters of the world tea market, Kenya, China India, Sri Lanka Vietnam and Malawi are the highly active countries that compete for each other in the vigorous tea business environment (Kasturiratne D, 2008). When the present positions of tea exporting countries are concerned, Kenya is leading as the largest exporter whereas China and Sri Lanka have the second and the third positions respectively and the other leading exporting countries are Taiwan, Bangladesh and Malawi (Sri Lanka Tea Board 2016).

Having secured a place in the world tea production as well as tea export, Sri Lanka has earned a reputation among tea producing countries. Further, there are about one million employees, directly and indirectly, involved in the Sri Lankan tea industry. Besides, around $15 \%$ of foreign exchange is generated from the tea industry (Sri Lanka Export Development Board 2016).

To have economic benefits to the country the tea industry should be competitive at a sustainable level over the other producers and the exporting countries in the world. Sri Lanka should define its strategy for competitiveness in the world tea market by creating a position with stability in the tea market place and coping with the competitive process productively (Herath and Silva 2011). Sri Lanka needs to have a unique competence that makes the tea sector to differentiate itself from the tea exporting countries and attains competitive advantage. New product development, the low marginal cost of production superior product attributes that enhance the quality and state of art distribution mechanism are the unique competencies that needed to be competitiveness that Sri Lankan tea should have to gain competitiveness in the global tea industry for an extended period (Pitts and Lei 2007).

The data analysis revealed that the percentage share of Sri Lanka in the world tea market has been significantly decreased continuously, whereas the share of Kenyan tea is being increased with a higher growth rate penetrating Sri Lanka's traditional markets. It reveals that Kenya is more competitive which adversely affects the marketing of Ceylon tea. This indicates that Sri Lanka is losing its tea export competitiveness to other major tea exporters. 
Therefore, to implement an effective marketing communication system, it is needed to assess the competitiveness of major tea exporters in importing countries.

The overall objective of this study is to find out the competitiveness of Ceylon Tea in the global tea market. Employing suitable models to determine the competitiveness of Ceylon tea and estimating the growth, composition, and competitive effect to differentiate the countries that are competitive, and have the potential to be competitive and accordingly make recommendations for suitable promotional policies in implementing marketing communication strategies were the objectives specific for this study. There had no model been tested to determine the competitiveness of Ceylon tea. Therefore, it was vitally essential to analyse the existing and potential markets for their competitiveness; besides, applying the model at two phases, it is expected to see the change of the output of the model over time and observe the impact of different marketing policies and strategies applied at two phases as deem necessary.

\section{Materials and Methods}

As there had been no similar case study in the tea sector the following Indian study on the competitiveness of pepper was taken as the experience for this study. According to the study, the import growth effect represents the potential change in total exports of a country assuming a constant market share of the base period. The market effect is the difference between the market-specific growth effect and overall import growth effect. The competitive effect is the residual after subtracting import growth effect and market effect from the total change in exports. In the study import growth effects for Indian pepper were 41, -18, 25, -20, 10 and 19 in the USA, USSR, Canada, Italy Germany, and other markets respectively. Market effects were $-15,27,8-27,2,-3$ in the USA, USSR, Canada, Italy Germany, and other markets respectively. Competitive effects were $74,-55,68,-53,-92$ and -116 in the USA, USSR, Canada, Italy Germany, and other markets respectively. The above results showed that import growth, market and competitive effects of Indian pepper are positive in the USA and Canadian markets indicating competitiveness in these two markets for Indian pepper while in other markets it was not competitive. However, the overall competitive effect is negative $(-104)$ and therefore, it is required to adopt strategies to make Indian pepper competitive in the world market (Mamatha and Chengappa 1997).

The requirement of data was met collecting from sources of secondary data such as the International Tea Committee, the Sri Lanka customs, the Sri Lanka Tea Board, the Central Bank of Sri Lanka, and the Export Development Board of Sri Lanka. Other sources of publications such as research articles, webreferences, annual reports, journals and books were also associated with the extraction of data.

The two criteria for selection of fifteen countries which import Ceylon tea were the quantity of export and the potential of countries to import Ceylon Tea. Selected countries with its quantity of imports (in million kg.) and the 
percentage (within the brackets) were Russia (44.1, 14.6\%), Turkey (38.5, 12.8\%), Iraq (1.3, 7.4\%), Iran (31, 10.3\%), Azerbaijan (10, 3.3\%), Syria (15.6, 5.2\%), Libya (9, 2.9\%), Germany (7.8, 2\%), Australia $(2.5,0.73 \%)$ and India (1.9, 0.63\%) (Sri Lanka Tea Board 2015). Data extracted during the past thirteen years from 2003 to 2015 was used for carrying out the research. Data included the annual total import of Ceylon Tea by each country, annual total import by each country and total annual import of tea (from all tea importing countries) by each country in terms of quantity and US\$ value. The Constant Market Share model was employed as analytical tool to evaluate the competitive advantage of Ceylon Tea. According to the Constant Market Share model if the market share of any country is increased in a particular market that country should have a competitive advantage over the other countries. Several models can be used to analyse the competitiveness and effects of trade liberalization on trading in a particular country. Mamatha and Chengappa (1997) showed that "The constant market share model (CMS) is the most convenient and suitable to analyse bilateral trade flows between two countries".

The relatively simple way of analysis, the ability to provide insight into competitiveness in designing export strategies and impact of existing policies evidence of using this model in the Indian pepper industry for the same purpose are the key factors that lie rationality of selecting this model. Foundation with strong theories as well as concisely summarized key aspects of the large volume of data is the major strength of the CSM model. Whereas a model being descriptive and not causal, the chance of flowing measurement error directly into results and varying the share of trade from year to year specially at the aggregate levels, are the major weak area of this model. The simple way of analysing complex growth patterns was the main reason for selecting the CSM model over others (Gilbert 2017).

This model was employed to disintegrate change of a Ceylon tea market of a country into growth, competitive and market composition effects assuming that a country's export share in a Ceylon tea market hasn't been changed over time. As per the model, the total change of exports between two periods is the sum of import growth effect, market effect, and competitive effect. The import growth effect represents the potential change in total exports of a country assuming a constant market share of the base period. The market effect is the difference between the market-specific growth effect and overall import growth effect. The competitive effect is the residual after subtracting import growth effect and market effect from the total change in exports.

\section{Data analysis}

Evaluation of competitiveness in Ceylon tea was done employing Market Share Model. The model was arranged with the following expressions and formula.

The total exports of Sri Lanka to a selected country during period 0 (base period).

$q i=$ Export Ceylon Tea to the selected country. 
$M=$ Rate (percentage) of increment of the total imports of the selected country from 0 to $t$ (period).

$m i=$ Rate (percentage) increment of the total tea imports of the selected country from 0 to t (period).

If Sri Lanka maintains its export market share in a particular country's market, Sri Lanka's exports to a particular country could increase by $M Q$.

$$
\begin{aligned}
& \Delta Q=M Q \rightarrow(1) \\
& Q(t) Q(0)=M Q(0)+Q(t) Q(0) M Q(0) \rightarrow 2
\end{aligned}
$$

The exports of Sri Lanka to particular country consists of many commodities and for a tea the equation was,

$$
\begin{aligned}
& q i(t) q i(0)=m i q i(0)+q i(t) q i(0) m i q i(0) \\
& \rightarrow(3) \\
& Q=q i=q 1+q 2+\ldots .+q n \rightarrow(4)
\end{aligned}
$$

By aggregating equation (3) for all commodities imported by particular country and by rearranging,

$$
\begin{aligned}
& Q(t) Q(0)=q i(t) q(0) \\
& =\operatorname{miqi}(0)+\{q i(t) q(0) \operatorname{miqi}(0)\} \\
& \operatorname{Mqi}(0)+\{(\operatorname{miM}) q i(0)\}+\{q i(t) q i(0) \operatorname{miqi}(0)\} \\
& \quad \rightarrow(5)
\end{aligned}
$$

$(\mathrm{r})=$ competitive effect (an unexplained residual difference).

This analysis is based on the shares of imports in fifteen destinations of Ceylon tea maintained by Sri Lanka exports assuming that if competitiveness is not changed, Sri Lanka should maintain the constant share of the export market. To avoid the annual variation of exports and imports, averages of the three consecutive years (triennium averages) were taken for the analysis. Average shares over a longer period or moving averages can be a remedial action to correct the year to year of trade share variations especially at the aggregate level. The competitiveness was assessed for two phases so that change competitiveness for Ceylon tea in a selected country over time could be judged. The first phase is from 2003 to 2010 and second phase is from 2010 to 2015. For the first phase triennium average of 2003 to 2005 as the base period and the same of 2008 to 2010 as the period after base period were considered. Triennium average of 2008 to 2010 as the base period and the same of 2013 to 2015 as the period after base period were considered for second phase. All the value of exports and imports were converted into US\$ to nullify the inflationary pressure.

In the interpretation of results, a market to be $Q(t) Q(0)=M Q(0)+\{(m i M) q i(0)\}+\{q i(t) q(0) m i q i(0)$ dompetitive to Ceylon tea, the value for $Q=(g)+(c)+(r) \rightarrow(6)$ competitive effect should be positive. The countries having negative values but relatively $(g)=$ growth effect (general increment selected low, those countries can be ranked as countries country's imports).

(c) = commodity composition (market effect). having potential to become competitive. When a positive figure resulted in market effect, that 
particular country has a good demand for Ceylon tea or other origin teas.

\section{Results and Discussion}

\section{The first phase (from 2003 to 2010)}

Table 1 consists of the three effects resulted from the analysis of the Constant Market Share model for the first phase (2003 to 2010).

As per Table 1, only three countries got positive results for competitiveness accordingly Ceylon tea has got competitiveness in Japan, Germany and the USA. It means that Sri Lanka has successfully gained the advantage of increased demand of Ceylon tea in those markets. According to comparative figures achieved for three countries for competitive effect, Japan has the highest value followed by Germany and the USA. According to Tea Board information, Sri Lanka had done a lot of promotion during this period to penetrate the Japanese market. However, demand may have occurred from the unique taste and the quality of Ceylon tea in those markets. Iran, Turkey Iraq, Russia, Syria, Azerbaijan, Kuwait, China, Australia and India have positive values composition effect, indicating higher demand for tea. Sri Lanka has failed to obtain the advantage of increased demand for tea in those markets. Having shown comparatively low negative values for competitive effect, Libya, Azerbaijan, India, UK and Australia shows some potential to become competitive. This suggests that the demand for Ceylon tea in those markets was being grown.

Consumption of Ceylon tea would be increased in the markets which may be competitive for Ceylon tea.
There had been a high negative competitive effect for Ceylon tea in Turkey, Russia, Iran, Iraq, Syria, Kuwait and China markets in the first phase of analysis.

Table 1: Analytical results for the first phase (2003 to 2010)

\begin{tabular}{llll}
\hline $\begin{array}{l}\text { Selected } \\
\text { Country }\end{array}$ & $\begin{array}{l}\text { Growth } \\
\text { Effect }\end{array}$ & $\begin{array}{l}\text { Market } \\
\text { Effect }\end{array}$ & $\begin{array}{l}\text { Competitive } \\
\text { (residual) } \\
\text { Effect }\end{array}$ \\
\hline Turkey & 9583 & 21959 & -20434 \\
Russia & 107426 & 48693 & -98941 \\
Iran & 53704 & 242791 & -216781 \\
Iraq & 53044 & 10785 & -34101 \\
Syria & 85845 & 11644 & -42038 \\
Libya & 8575 & -846 & -732 \\
Kuwait & 14528 & 133120 & -124949 \\
Azerbaijan & 26310 & 5448 & -3157 \\
Japan & 11806 & 244 & 12402 \\
Germany & 7282 & 5469 & 1028 \\
China & 3568 & 11026 & -11525 \\
India & 3101 & 1640 & -3179 \\
UK & -434 & -522 & -520 \\
USA & 1328 & 3016 & 826 \\
Australia & 6397 & 3110 & -1024 \\
\hline
\end{tabular}

\section{The second phase (from 2010 to 2015)}

According to the results in the table 2 for the second phase of analysis by the Constant Market Share model, Ceylon tea has positive competitive effects in 8 countries out of 15 countries, Turkey has the highest followed by Russia, Kuwait, Japan, Germany, India, USA and Australia. As per the analysis of the first phase, Ceylon tea was competitive only in 3 countries which have kept competitiveness in the second phase as well. Iran, Libya, Azerbaijan, and the UK have shown some potential to become competitive for Ceylon tea having comparatively low negative values for competitive effect. All the countries except Syria 
and UK have positive values for market effects showing the expanded market for tea.

Table 2: Analytical results for the first phase (2010 to 2015)

\begin{tabular}{llll}
\hline $\begin{array}{l}\text { Selected } \\
\text { Country }\end{array}$ & $\begin{array}{l}\text { Growth } \\
\text { Effect }\end{array}$ & $\begin{array}{c}\text { Market } \\
\text { Effect }\end{array}$ & $\begin{array}{c}\text { Competitive } \\
\text { Effect }\end{array}$ \\
\hline Turkey & 27026 & 7534 & 48140 \\
Russia & 7923 & 10457 & 26560 \\
Iran & 5930 & 54372 & -4770 \\
Iraq & 36331 & 23359 & -16978 \\
Syria & 13551 & 1697 & -32786 \\
Libya & 867 & 3274 & -1952 \\
Kuwait & 5038 & 2705 & 5691 \\
Azerbaijan & 8025 & 11059 & -3364 \\
Japan & 461 & 295 & 2770 \\
Germany & 808 & 3948 & 5649 \\
China & 8003 & 31781 & -26023 \\
India & 43 & 4 & 56 \\
UK & -104 & -64 & -1889 \\
USA & 2102 & 3114 & 3992 \\
Australia & 346 & 290 & 1433 \\
\hline
\end{tabular}

\section{Comparing the competitive effect gained} by the countries in the first and the second phases.

Table 3 shows the comparison of the competitive effect of Ceylon tea in first and the second period. When the figures for competitiveness for two phases (in two columns) are compared, except for Libya and Azerbaijan, there is an improvement in competitiveness having values become more positive and less negative in the second phase.

Two countries India and Australia have shown the potential to be competitive in the first phase, have become competitive in the second phase. The competitive effect means that Sri Lanka has successfully gained the advantage
Table 3: Comparing the competitive effect of Ceylon tea in two periods

\begin{tabular}{lll}
\hline $\begin{array}{l}\text { Selected } \\
\text { Country }\end{array}$ & $\begin{array}{l}\text { Competitive } \\
\text { Effect in the } \\
\text { first phase }\end{array}$ & $\begin{array}{l}\text { Competitive } \\
\text { Effect in the } \\
\text { second phase }\end{array}$ \\
\hline Turkey & -20434 & 48140 \\
Russia & -98941 & 26560 \\
Iran & -216781 & -4770 \\
Iraq & -34101 & -16978 \\
Syria & -42038 & -32786 \\
Libya & -732 & -1952 \\
Kuwait & -124949 & 5691 \\
Azerbaijan & -3157 & -3364 \\
Japan & 12402 & 2770 \\
Germany & 1028 & 5649 \\
China & -11525 & -26023 \\
India & -3179 & 56 \\
UK & -520 & -1889 \\
USA & 826 & 3992 \\
Australia & -1024 & 1433 \\
\hline & &
\end{tabular}

of the increased demand of Ceylon tea in those markets. However, demand may have occurred from the unique taste and the quality of Ceylon tea in those markets. Although Iran, Iraq, Libya, Azerbaijan and China have shown high composition effect (expanded market for tea), Ceylon tea has failed to grab the advantage of increased demand for tea in those markets.

Markets that were shown to be competitive for the Ceylon tea in the first phase were still competitive for Ceylon tea.

Accordingly, Libya, Azerbaijan and the UK markets have been potential markets for Ceylon tea since year 2003 to 2015. In addition, Iran market can be considered as an added potential market to be competitive for Ceylon tea in the second phase.

Though there is improvement in competitive effect for Ceylon tea in Iraq and Syria, China 
have higher negative effects as per the analysis in the second phase. According to the analysis done for the first phase, there had been no competitiveness for Ceylon tea in Turkey, Russia and Kuwait markets. However, in the second phase, Ceylon tea has strongly emerged as competitive in those countries. This may be due to the awareness of health benefit and other campaign launched by leading the Ceylon tea brand and Sri Lanka Tea Board. Further, in the first period, there was no considerable competitiveness of Ceylon tea in the Iran market. In the second period, though Iran was having a negative value for the competitiveness of Ceylon tea it has a large improvement compared to the first phase. This situation is justified by Iran becoming one of the top buyers of Ceylon tea in 2015. Altogether, there had been considerable improvements in the competitiveness of Ceylon tea towards the latter part of the second phase.

When empirical data of the export quantity and export revenue data of Ceylon tea, during the period in which the competitive analysis (2003 to 2015 ) is concerned, there had been a clear increase in export revenue towards the end of the second phase. This can be taken as a qualitative measure to justify the finding of the competitive analysis has increased the number of countries with competitive advantage and improvement in the overall competitiveness of 13 countries out of selected 15 countries (Fig. 1 and Fig. 2).

Fig. 1 shows quantity change over time from 2003 to 2015. According to the Fig. 1 the quantity of Ceylon tea export during period of the analysis, fluctuate around 300 million $\mathrm{kg}$ with no significant change over time.

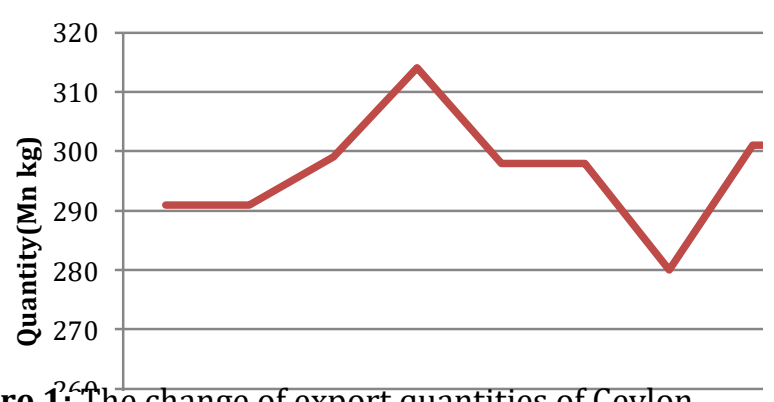

Figure 1: The change of export quantities of Ceylon tea from 2003 to 2015

Fig. 2 shows the value of export in term of US\$ from 2003 to 2015. This figure clearly shows that there is a significant increase in the total revenue nearly for the same amount of export (300 M.kg) during the second phase providing reasonable evidence to justify the finding of the above analysis claiming higher number of countries with a competitive advantage which increased the demand Ceylon tea generating more revenue.

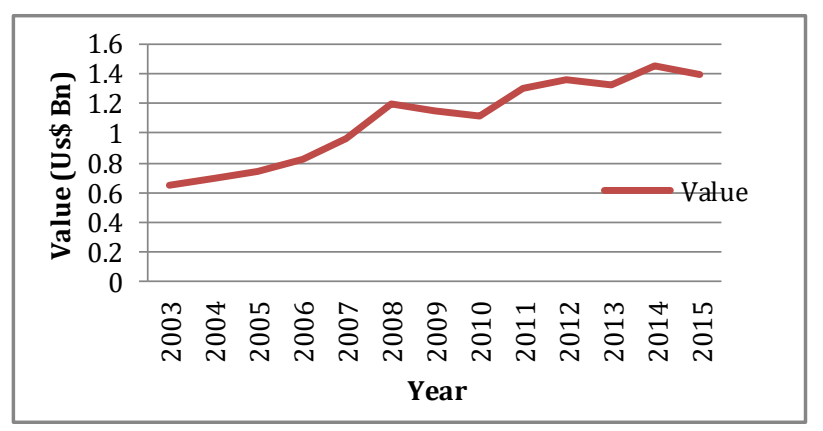

Figure 2: Change of annual Ceylon Tea export earnings from 2003 to 2015

When the overall effect of the competitiveness of the Ceylon tea is concerned, there has been a positive value for the competitiveness during second phase indicating that Ceylon tea maintains a competitive advantage in these markets.

According to the Fig. 3, the cumulative competitive effect of Ceylon tea of fifteen selected countries, it can be observed that the total cumulated competitive effects of all the selected countries have exceeded the cumulative growth 
effect and that of the composition (market) effect. Being having a positive value of competitive effect,

In general, Ceylon tea is competitive in the world (selected fifteen markets) market although there are five countries with low competitiveness.

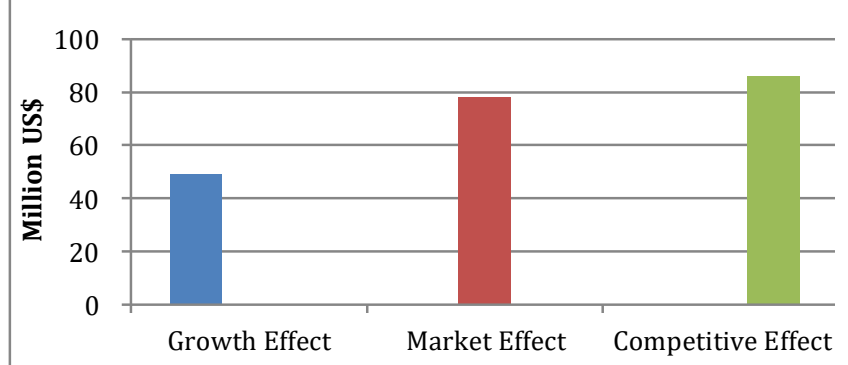

Figure 3: The comparison the 3 effects of Ceylon tea at the world (selected destinations) level.

\section{Conclusion}

When the competitiveness of Ceylon tea in the first phase (2003 - 2010) is considered, it can be concluded that Ceylon tea had gained competitiveness only in markets of Japan, Germany and the USA. However, during the second phase (2010 - 2015), Ceylon tea has gained competitiveness in 8 countries out of 15 countries tested. They are Russia, Kuwait, Japan, Germany, India, the USA and Australia.

Potential markets to be competitive for the Ceylon tea in the first phase (2008-2010) are Azerbaijan and UK, Libya, and India. Iran, Libya, Azerbaijan, and the UK have shown some potential to become competitive for Ceylon tea in the second phase (2008 to 2015). The were no considerable competitive effect for Ceylon tea in Iraq, Syria, and China according to the constant market share analysis in both the phases. In recent years, Ceylon tea could capture the share of many markets exceeding the growth effect and the composition (market) effect.
CMS model is a relatively simple model that can be employed with available data to measure the competitiveness in a particular market. The three output effects growth, market (commodity) and competitive are valuable information that can be utilized market promotion strategies. Application of the CMS model at two phases shows the change of competitiveness of countries over time which is useful to evaluate the impact of existing policies. Strategies applied during the second phase are more effective than that of the first stage.

\section{Recommendation}

Tea promotional campaigns or effective marketing strategies should be adopted base on the findings of the analysis by CMS model. Markets with potential (less negative value for competitiveness) and with high value for market effect should be given priority as they can be a push to a competitive level with few efforts. The marketing strategies should be formulated according to the findings (three effects). When a country has a negative value for market effect generally drinking tea should be promoted first and then Ceylon tea.

Promotional marketing communication system should be adopted not only in the market found to be potential but the same should be applied in markets found to competitive to sustain the demand. To be more competitive in the global market, Sri Lanka should match the strengths of the competitor who are strong with costminimizing and quality standard of product.

The Constant Market Share Model (CMS) is a suitable tool to measure the competitiveness of destinations of Ceylon tea as it is a simple (comparatively) and can be employed accessible data. 
Sri Lanka must look for new markets in politically and economically stable markets to export teas rather than being dependent on Russia and Middle Eastern counties which are vulnerable to crisis. To enter and establish in such markets it is essential to diversify tea industry base on customer requirement of intended markets with branded value-added tea products.

To consolidate in already captured markets while adopting effective marketing commutation strategy, in order to create fair and competitive, trade and non-trade barriers must be removed. Trade barriers such as tariff and product restrictions can be removed by trade agreements and effective diplomatic mediation and non-trade barriers can be removed by meeting international standards (Maximum Residual Levels (MRL) Food Safety Certifications: ISO2200 and HACCP, Ethical and Sustainability certifications) and standards specific to some countries (Microbial standards, Moisture Levels, packing standards and etc.). Confirming to international standards must be promoted as it removes the barrier to enter into some markets as well.

To be more competitive in the global market, productivity at every production stage should be improved and it would decrease the marginal cost of production of Ceylon tea and increase the competitiveness of Ceylon tea while meeting international and country-specific quality, food safety standards.

\section{References}

Gilbert J, (2017) Constant Market Share Analysis Part I: Decomposition of Values. Proceedings of the Capability Building Workshop in Laos: 1-6.
Herath H, and Silva S, (2011) Strategies for Competitive Advantage in Value Added Tea Marketing. Tropical Agricultural Research 22(3); 251-262.

Kasturiratne D, (2008) An Overview of Sri Lankan Tea Industry: An Exploratory Case Study. The Marketing Review 8(4) (Winter): 367-381.

Majumder A, Bera B, and Rajan A, (2015) Tea Statistics, Global Scenario Export (in volume terms): 2010-2013.

Mamatha B, Chengappa P, (1997) Competitiveness of Indian pepper exports. Indian Journal of Agricultural Marketing 11(1 \& 2): 48-51.

Pitts R, and Lei D, (2007) Strategic Management, Building and Sustaining Competitive Advantage 4.

Sri Lanka Export Development Board, (2016) Industry Capability Report Tea. Sri Lanka Export Development Board: 10.

Sri Lanka Tea Board, (2016) Tea Market Update. Colombo: Tea Promotion Division- Sri Lanka Tea Board: 3-11. 